\title{
Development of a Learning Model of Quadric Surfaces With Augmented Reality and Didactic Engineering
}

\author{
https://doi.org/10.3991/ijim.v15i22.25341 \\ L.H. Carmona-Ramírez ${ }^{(\bowtie)}$, V. Henao-Céspedes \\ Universidad Católica de Manizales, Manizales, Colombia \\ lucarmona@ucm.edu.co
}

\begin{abstract}
Augmented reality (AR) is an emerging technology that has permeated different spheres of life, one of them is education, and specifically the teaching-learning process at different educational levels and objects of study. For this reason, this paper presents the development of a learning model of quadric surfaces mediated by a mobile AR application and based on didactic engineering. The model was applied to a group of environmental engineering students of the Catholic University of Manizales. To obtain information on the use of the application and the learning results obtained, some intervention instruments were developed. The students stated that the use of AR allowed them to better understand the concepts of quadric surfaces, even more so in a time of pandemic by COVID-19, where education was highly measured by ICTs.
\end{abstract}

Keywords - augmented reality, didactic engineering, quadric surfaces, technology-enhanced learning

\section{$1 \quad$ Introduction}

The teaching of multivariate calculus, in some undergraduate programs, is reduced to the study of abstractions assuming a strong conceptual mastery of the students and predominantly the use of algebraic and analytical representations. Geometric representations play a very important role in the didactic process, which presupposes the need to implement methodologies that favor this type of representations [1]. Thus, most calculus courses emphasize numerical, algebraic, symbolic and logical aspects, but, in general, students are little motivated to reason from the graphical aspects that arise from the concepts themselves. Consequently, it can happen that students who pass calculus courses that emphasize the manipulation of formulas do not recognize the concepts studied when they are presented with graphs and practical problems related to their environment [2].

With the appearance of emerging technologies that can be applied in different spheres of life, such as Augmented Reality (AR) [3], [4], the learning of multivariate calculus has been favored in aspects, such as those related to the representations of three-dimensional objects, where the entities move beyond the plane and have their own movement [5]. This type of dynamic representation of mathematical processes allows more effective mental manipulations than those that could be achieved from a static text and images in a book [6]. 
Thus, this paper presents the development of a learning model of quadric surfaces, and the results of its application to environmental engineering students of the Catholic University of Manizales, Colombia, with the objective of analyzing how a three-dimensional learning environment mediated with AR favors the learning of quadric surfaces from an instrumental approach. For this development, didactic engineering [7] and the theory of instrumental genesis (IG) [8] were used, [9] where the use of technology as an instrument for the teaching-learning of mathematics was favored, with a correct instrumental orchestration allowing students to obtain a process of instrumental genesis from the didactic engineering design of the teacher, considering that, according to [10] orchestration allows generating a solid and convergent mathematical discourse, and therefore technology has been gaining an important role in the learning process.

\section{About augmented reality and didactic engineering}

An AR system complements the real world with computer-generated virtual objects that seem to coexist in the same space as the real world [11], in that sense AR becomes a modern method that supports self-learning and privileges learning according to the capabilities of each student. Different studies on AR and its application as a tool for learning mathematics have been found in the scientific literature, among which stand out Barraza et al [12] who implemented a software for the development of AR applications, specifically to plot a quadratic equation, concluding that the use of AR can help improve the teaching-learning process, motivate students and can be an alternative technology to revolutionize the learning paradigm in the future.

Some authors, such as [13], [14], [15], highlight the integration of digital technology in the mathematics learning process to strengthen the development of spatial skills in students, which could positively influence in reducing the phenomenon known as mathematics anxiety, thus impacting STEM (Science, Technology, Engineering and Mathematics) education. The authors conclude from their studies that AR-mediated learning allows students to exploit, obtain and understand the symbolic nature of mathematics. Thus, [16] affirms that students who have a learning process mediated by AR achieve greater learning gains than those students who do not have these technological tools.

Regarding the area of multivariable calculus in [5] apply two AR tools, which allow students to develop their mathematical visualization skills, associated with spatial intelligence, (see Figure 1), since according to [11] the use of augmented reality increases student performance and visual thinking.

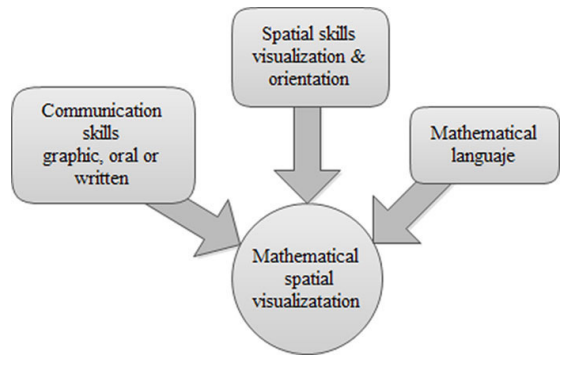

Fig. 1. Elements of mathematical spatial visualization 
The application of AR in the teaching-learning process allows the application of a pedagogy associated with the use of mobile technologies, such as the inverted classroom, in the learning of mathematics, which is relatively new. According to [17] the application of inverted learning (inverted classroom) has proven to be an effective techno-pedagogical approach. On the other hand, with the use of inverted learning, motivation and skills increase in the analysis and representation of graphs. Also in [18], it indicates that the application of inverted classroom promotes independent learning and encourages students to work together with other peers. In [19] the use of the inverted classroom in the learning of multivariate calculus is exposed, a comparison between the traditional model and the inverted classroom is made, concluding that students who were under the inverted classroom model indicated greater communication during class, obtaining gains in academic performance.

Finally, the AR applied to the learning of an object of study, must be directed by a method that allows the generation of teaching situations, this method was proposed in [20] and called didactic engineering, which is composed of 4 phases, which are:

Phase 1-Preliminary analysis: It is based on the objectives initially set and on the needs observed in the students [21]. Within this systemic engineering process, the following aspects should be considered, which provide an answer to a paradigmatic question [22]:

1. Epistemological analysis of the contents contemplated in the teaching.

2. Analysis of traditional teaching and its effects.

3. Analysis of the conceptions, difficulties and obstacles.

4. Analysis of the constraints where the didactic action is to be implemented.

Phase 2-Conception, a priori analysis: It consists in making the decision to act on a certain number of system variables not fixed by the constraints, which are usually called command variables [20]. Didactic engineering establishes two types of variables or two levels: macro and micro didactic. The first has as its object the study of a given subject, seeking to understand the complexity of the phenomena that can occur in the classroom. Macro-engineering comprises the complexity of micro-engineering together with aspects related to the teaching and learning process [23].

Phase 3-Experimentation: It allows to approximate the practical results with the theoretical foundations.

Phase 4-A posterior analysis: The A posterior analysis is the center of research in didactic engineering where the results are shown and the acquired learning and skills are evidenced, as stated by [24], it is a matter of considering such analysis in a systemic, particular, synchronic and constitutive perspective. That is, under the consideration that a fundamental didactic criterion is the establishment and articulation of the different factors that are necessarily involved in the didactic design and in the execution of the tasks.

Didactic engineering has been applied in several investigations on different objects of study such as: financial mathematics in higher education [23], for the development of a didactic sequence that would allow students to deepen their knowledge of financial mathematics using a financial calculator emulator. In geometry [25], with a historical-epistemo-logical inquiry of Euclid's geometry to identify difficulties in students to solve geometric problems. Differential calculus [26], development of several didactic sequences with the objective of promoting the correct conceptual understanding 
of the course topics. Inferential reasoning [27], focused on the understanding of the Fibonacci model from a didactic transposition of the concepts of pure mathematics, for an easy understanding, thanks to didactic engineering. The didactic sequences proposed from didactic engineering should allow the generation of an instrumental genesis (IG) between the artifact (application, software, among others) and the subject (student), as stated by [8], in such a way that the subject, making use of the artifact, can provide it with conditions for it to be constituted as an instrument. This instrumental genesis, according to [28], deals with the mutual evolution of an artifact and its uses for a specific purpose within a given environment, as is the case, according to [29], of transforming digital tools into mathematical instruments, which then become part of the cognitive schemas of students.

\section{Methodological design}

This research work is framed within the mixed approach of an instrumental case study, whose purpose is to provide knowledge inputs to a research problem [30], in this case we sought to answer the following question: How does a three-dimensional learning environment mediated with RA favor the learning of quadric surfaces? The study population consisted of 22 fourth semester students of environmental engineering at the Catholic University of Manizales - Colombia. The methodological design of the research (see Figure 2) was based on the four phases of didactic engineering [20], [22] from the conceptualizations of Trouche [9] and Rabardel [31].

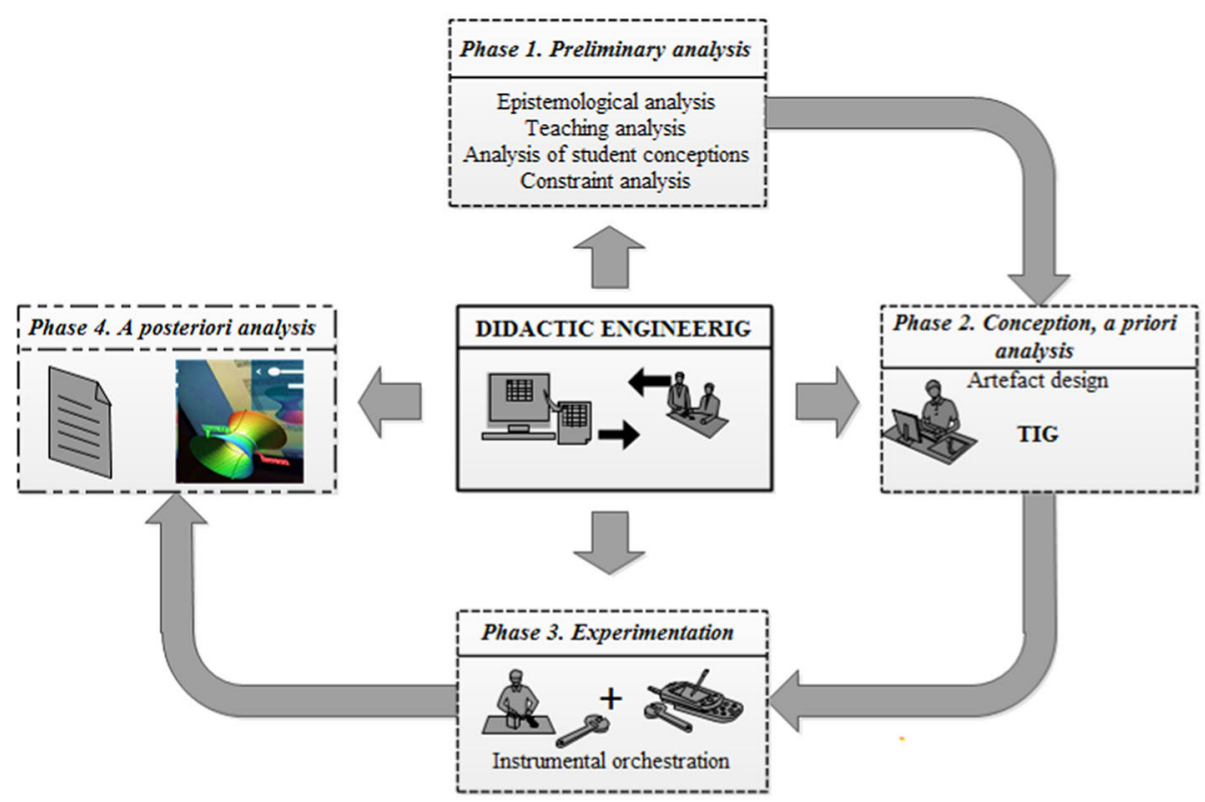

Fig. 2. Methodological scheme applied 
Phase 1: In this work, questions associated with each of the four aspects mentioned above were posed, which can be seen in Table 1.

Table 1. Fundamental aspects of the preliminary analysis

\begin{tabular}{|c|c|c|c|c|}
\hline & $\begin{array}{c}\text { Epistemological } \\
\text { Analysis }\end{array}$ & Teaching Analysis & $\begin{array}{l}\text { Analysis of Students } \\
\text { Conceptions }\end{array}$ & $\begin{array}{l}\text { Analysis of } \\
\text { Constraints }\end{array}$ \\
\hline $\begin{array}{l}\text { Paradigmatic } \\
\text { questions }\end{array}$ & $\begin{array}{l}\text { What is the role of } \\
\text { conic sections in } \\
\text { the development of } \\
\text { quadric surfaces? }\end{array}$ & $\begin{array}{l}\text { What teaching } \\
\text { resources can be } \\
\text { used to improve } \\
\text { the teaching of } \\
\text { quadratic surfaces? }\end{array}$ & $\begin{array}{l}\text { What preconceptions } \\
\text { do students have } \\
\text { about three- } \\
\text { dimensional space } \\
\text { and its representations } \\
\text { in the plane? }\end{array}$ & $\begin{array}{l}\text { How difficult is } \\
\text { it to use RA for } \\
\text { teaching quadric } \\
\text { surfaces? }\end{array}$ \\
\hline
\end{tabular}

Phase 2: Conception, a posteriori analysis: In this work we resorted to the use of macro-didactic or global and micro-didactic or local variables.

Macro-didactic variables: At this time an augmented reality APK application called "Quadric Surfaces" was developed, using the Vuforia engine [32] and Unity [33] software. Unity was used for the construction of the AR targets, on the other hand, for each of the quadric surfaces that would be studied in the course, a target was generated with Vuforia engine, in Figure 3 it is possible to observe a target.

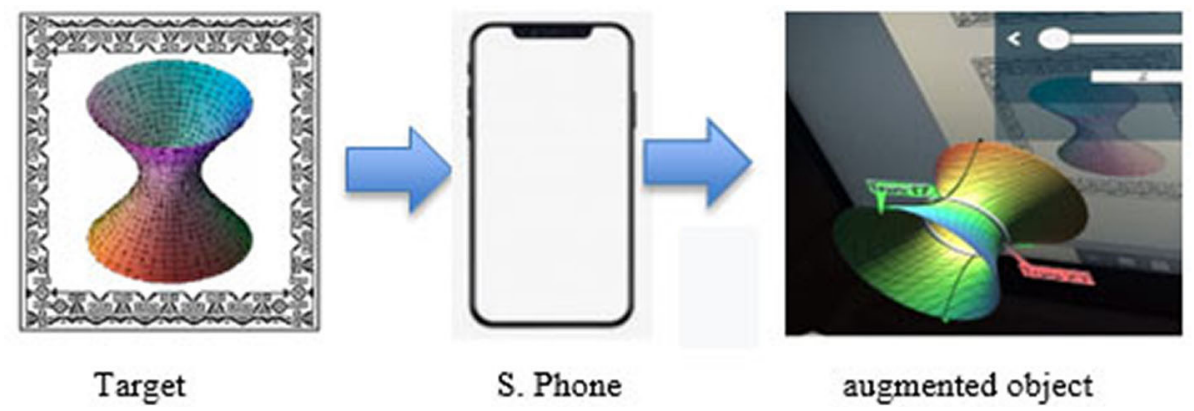

Fig. 3. Apk modeling process with vuforia and unity

Micro-didactic variables: These are those concerning the local planning of engineering, i.e., the organization of the didactic sequences with which students interact to mediate learning. To this end, two intervention instruments (guides) were constructed, which were designed with the MI approach [31] based on a situation or cognitive conflict [34] that motivated the search for answers inherent to the situation presented. The design of the guides took into account the two dimensions proposed in the MI, instrumentation and instruction-mentalization, the former emphasizing the schemes of appropriation and the latter the schemes of instrumented action.

Phase 3: This was developed in two moments. In the first moment, each student individually approached the tool and thus appropriated the schemes of use of the instrument, that is to say, reached instrumentalization, which consists of the procedural approach to the artifact through discovery, personalization and transformation. In the second moment, a collaborative work was developed where the use of the schemes 
of instrumented action prevailed, i.e., instrumentation. During the passage from one moment to the other, the instrument became the only mediator between the student and the task, giving rise to instrumental orchestration, which is when the instrument is endowed with potentialities and transformed [8], [31] producing the didactic configuration and the actions on the objects. Figure 4 shows the underlying processes applied during this phase.

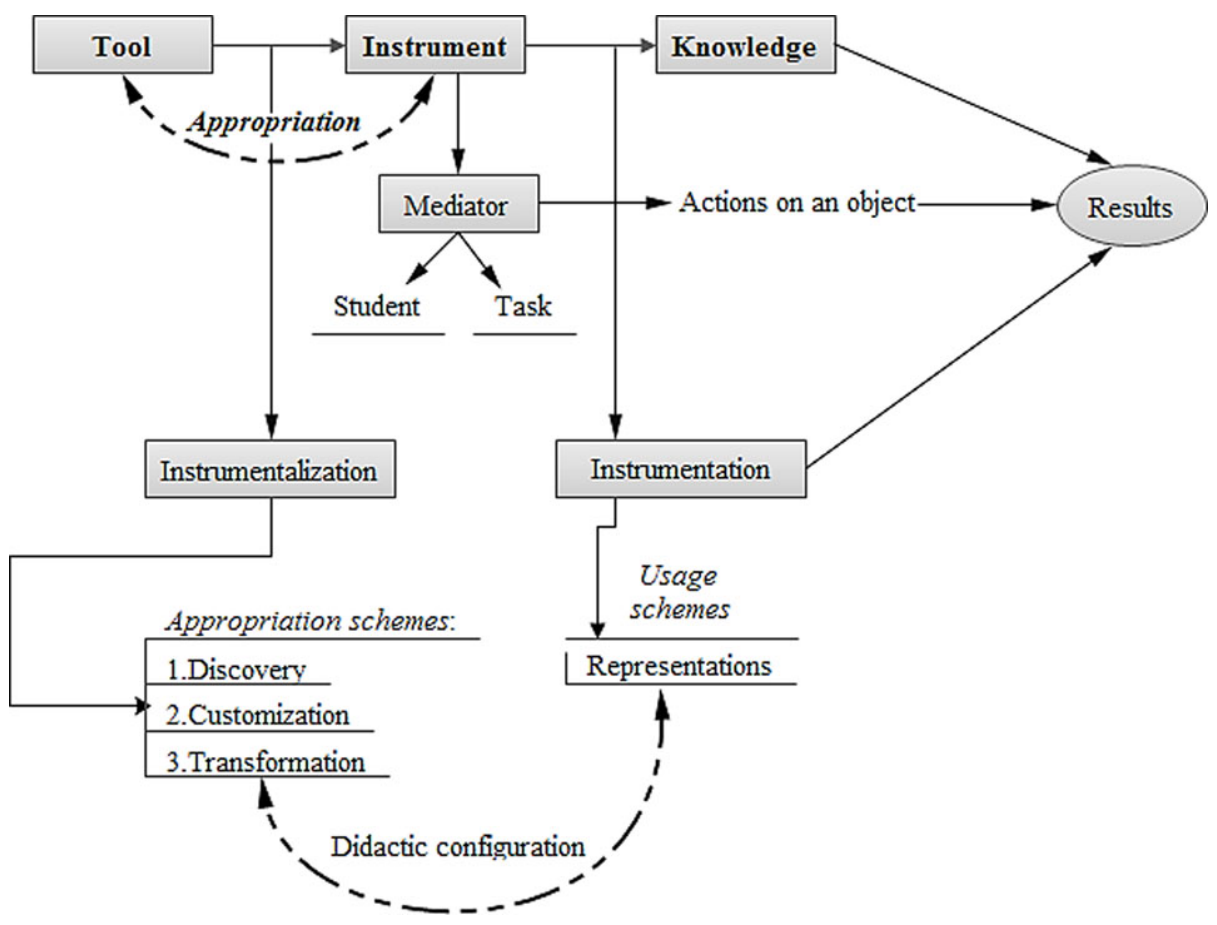

Fig. 4. IT-supported process design

Phase 4: During the previous phases, the work concentrated on the procedural aspects, on the development of the student's capacities and limitations and of the instrument. For the a posteriori analysis, the results obtained from the development of the tasks proposed in the intervention instruments were analyzed. In the design of the work, 4 problems were proposed in which the students had to respond according to the two moments of the MI. Tables 2 and 3 show in detail the routine that the students described when they developed the task. Table 3 shows three types of representations of the instrumented action schemes (algebraic, graphic and image or other), these were chosen because they are the most used by students when solving problem situations [35]. 
Table 2. Schemes of appropriation of the use of the instrument

\begin{tabular}{|l|l|l|l|}
\hline \multicolumn{1}{|c|}{ Appropiation Schemes } & Discovery & Customization & Transformation \\
\hline Explain how you did it & & & \\
\hline
\end{tabular}

Table 3. Instrumented action schemes in problem solving

\begin{tabular}{|l|l|l|l|}
\hline \multicolumn{1}{|c|}{ Instrumented Action Plans } & Algebraic & Chart & Image \\
\hline Procedure & & & \\
\hline
\end{tabular}

\section{$4 \quad$ Results and discussion}

The results obtained from the application of the intervention instruments, in Phase 3 and 4, made it possible to know the appropriation and instrumented action schemes applied by the students in the solution of some problematic events, as well as the perception of the use of the application, and the evaluation of the learning of quadric surfaces acquired through the use of the application.

For the analysis of the appropriation schemes of use and instrumented action used by the students, the results obtained after the development of the tasks proposed in the intervention instruments were analyzed. According to the above, the students consigned in the matrix (Tables 4 and 5) the pro-cedures of each of the steps used in the development of the tasks. After observing and analyzing the responses obtained, it became evident that the Personalization appropriation scheme was the one with which the students felt most comfortable when using the application. As for the instrumented action scheme, most of the students used the three schemes to perform the procedures.

Table 4. Schematic of tool customization appropriation for the development of the traces of a hyperboloid of a sheet

\begin{tabular}{|l|l|l|l|l|}
\hline $\begin{array}{l}\text { One-leaf } \\
\text { hyperboloid }\end{array}$ & $\begin{array}{l}\text { Ellipse: } \\
\mathrm{Z}=0\end{array}$ & $\begin{array}{l}\text { Hyperbola: } \\
\mathrm{Y}=0\end{array}$ & $\begin{array}{l}\text { Hyperbola: } \\
\mathrm{X}=0\end{array}$ \\
$\frac{x^{2}}{a^{2}}+\frac{y^{2}}{b^{2}}=1$ & $\frac{x^{2}}{a^{2}}-\frac{y^{2}}{b^{2}}=1$ & $\frac{Y^{2}}{b^{2}}-\frac{Z^{2}}{c^{2}}=1$ & $\begin{array}{l}\text { In the XY trace } \\
\text { the slider shows } \\
\text { an ellipse, while } \\
\text { in the YZ and } \\
\mathrm{XZ} \text { traces the } \\
\text { sliders show } \\
\text { hyperbolic } \\
\text { traces. }\end{array}$ \\
\hline
\end{tabular}


Table 5. Example of an instrumented action scheme carried out by a group of students

\begin{tabular}{|l|l|l|l|}
\hline $\begin{array}{c}\text { Action Plan } \\
\text { Implemented }\end{array}$ & \multicolumn{1}{|c|}{ Algebraic } & \multicolumn{1}{|c|}{ Graph } & \multicolumn{1}{|c|}{ Other } \\
\hline Procedure & $\begin{array}{l}\text { After the algebraic } \\
\text { form of the } \\
\text { equation, a process } \\
\text { of equating the } \\
\text { equations of } \\
\text { the hyperbolic } \\
\text { paraboloid was } \\
\text { carried out, } \\
\text { obtaining as a final } \\
\text { result the following } \\
\text { equation: }\end{array}$ & $\begin{array}{l}\text { The hyperbolic } \\
\text { paraboloid } \\
\text { positively opens } \\
\text { a parabola on the } \\
\text { "X" axis which is } \\
\text { likely to intersect } \\
\text { one of the } \\
\text { infinite parabolas } \\
\text { of the elliptic } \\
\text { paraboloid. That } \\
\text { is the precise } \\
\text { point where they } \\
\text { can join. }\end{array}$ & $\begin{array}{l}\text { By means of the interpretation, knowing how } \\
\text { the elliptic paraboloid and the hyperbolic } \\
\text { paraboloid are graphically, we try to construct } \\
\text { the place where the 2 figures can intercept. }\end{array}$ \\
\hline$y^{2}=0$ & & \\
\hline
\end{tabular}

On the other hand, the intervention instruments made it possible to measure the perception of the application and its usefulness for learning the concepts of quadric surfaces. In relation to perception, Table 6 shows that, with respect to the size of the controls and letters, $50 \%$ consider that they are correct, while the other $50 \%$ are only in agreement. $25 \%$ of the students are unable to define whether the equations of the application are legible, but $75 \%$ of the students found the equations quite legible. For the point about the ease of use of the application to give answers to the questions posed in the didactic guide, $75 \%$ of the students agree that it was easy to use, while $25 \%$ do not decide to give an opinion on the matter. Regarding the manipulation of controls, $50 \%$ strongly agree that it is easy to use, while the remaining $50 \%$ only agree, this result is similar to the first assessment of the graphic environment (font size, controls, buttons). In relation to the speed in answering the questions with the use of the application, $50 \%$ agreed, $25 \%$ strongly agreed and the remaining $25 \%$ disagreed.

Table 6. Evaluation of the use of the application

\begin{tabular}{|l|c|c|c|c|c|}
\hline & $\begin{array}{c}\text { Strongly } \\
\text { Disagree }\end{array}$ & Disagree & Undecided & Agreed & $\begin{array}{c}\text { Strongly } \\
\text { Agree }\end{array}$ \\
\hline $\begin{array}{l}\text { Are the buttons, controls, and } \\
\text { fonts sized appropriately? }\end{array}$ & 0 & 0 & 0 & 50 & 50 \\
\hline Are the equations readable? & 0 & 0 & 25 & 0 & 75 \\
\hline $\begin{array}{l}\text { Do you consider that the } \\
\text { application was easy to } \\
\text { use (intuitive) to solve the } \\
\text { questions? }\end{array}$ & 0 & 0 & 25 & 75 & 0 \\
\hline $\begin{array}{l}\text { Did you find it easy to } \\
\text { manipulate the application } \\
\text { controls? }\end{array}$ & 0 & 0 & 0 & 50 & 50 \\
\hline $\begin{array}{l}\text { Was it fast enough to answer the } \\
\text { questions using the application? }\end{array}$ & 0 & 25 & 0 & 50 & 25 \\
\hline
\end{tabular}


In relation to the learning of quadric surfaces through the application, Table 7 shows that $75 \%$ of the students agree that the application allowed them to better understand the quadric surfaces, while $25 \%$ were very in agreement. $50 \%$ strongly agreed with the ease acquired through the application, to associate the equations with the respective quadric surface, $25 \%$ were undecided and the remaining $25 \%$ did not find this association to be easy. $75 \%$ of the students, thanks to the use of the application, managed to understand the concepts: traces, quadric surface equations, octants, indicating that they strongly agreed, while $25 \%$ agreed. Regarding the difference between the equations of each quadric surface, $50 \%$ strongly agreed that the application allowed them to understand the difference, while $50 \%$ only agreed.

Table 7. Evaluation of the utility of the application in learning quadric surfaces

\begin{tabular}{|l|c|c|c|c|c|}
\hline & $\begin{array}{c}\text { Strongly } \\
\text { Disagree }\end{array}$ & Disagree & Undecided & Agreed & $\begin{array}{c}\text { Strongly } \\
\text { Agree }\end{array}$ \\
\hline $\begin{array}{l}\text { ¿Did the process that you had to } \\
\text { follow to arrive at the solution of } \\
\text { the questions allowed you to better } \\
\text { understand the quadric surfaces? }\end{array}$ & 0 & 0 & 0 & 75 & 25 \\
\hline $\begin{array}{l}\text { ¿Was it easy to associate the } \\
\text { equation with the surface? }\end{array}$ & 0 & 25 & 25 & 0 & 50 \\
\hline $\begin{array}{l}\text { ¿Did this app allow you to } \\
\text { understand the concepts such as: } \\
\text { traces, quadric surface equations, } \\
\text { octants? }\end{array}$ & 0 & 0 & 0 & 25 & 75 \\
\hline $\begin{array}{l}\text { ¿Was it clear to you with the use } \\
\text { of the application, the difference } \\
\text { between the equations of each } \\
\text { quadric surface? }\end{array}$ & 0 & 0 & 0 & 50 & 50 \\
\hline
\end{tabular}

\section{Conclusions}

This paper presents the application of AR in the teaching-learning process of quadric surfaces, for which a mobile application was developed and applied to a group of students of the vector calculus course of the Catholic University of Manizales. The results obtained with the application of the intervention tool, on quadric surfaces, show that the use of AR, and specifically the application developed in this study, improves the understanding of these concepts, as indicated by $75 \%$ of the students. On the other hand, it is clear that the personalization appropriation scheme is the most used by the students, and as for the action scheme, most of the students used the three schemes to perform the procedures. It is expected that the developed application will be incorporated in the vector calculus component of the Catholic University of Manizales, with the respective improvements indicated by the students in this study, such as the graphic environment. Finally, the didactic sequence developed allowed the students to demonstrate an instrumental genesis with the artifact (application). 


\section{Acknowledgment}

The author thanks Universidad Católica de Manizales with Research Group on Education and Educa-tors Traning EFE and the Research Group on Technological and Environmental Development GIDTA.

\section{$7 \quad$ References}

[1] M. Montiel, M. R. Wilhelmi, D. Vidakovic, and I. Elstak, "Using the onto-semiotic approach to identify and analyze mathematical meaning when transiting between different coordinate systems in a multivariate context," Educ. Stud. Math., vol. 72, no. 2, pp. 139-160, 2009, doi: https://doi.org/10.1007/s10649-009-9184-2

[2] P. Vicente, E. Duarte, H. Trefftz Gómez, J. Restrepo, and T. A. Calder, "Estrategias de visualización en el cálculo de varias variables,” 2006. [Online]. Available: https://revistas.udea. edu.co/index.php/revistaeyp/article/view/6092

[3] F. Ozdamli and C. Hursen, "An emerging technology: Augmented reality to promote learning," Int. J. Emerg. Technol. Learn., vol. 12, no. 11, pp. 121-137, 2017, doi: https://doi. org/10.3991/ijet.v12i11.7354

[4] Z. Nurbekova and B. Baigusheva, "On the issue of compliance with didactic principles in learning using augmented reality," Int. J. Emerg. Technol. Learn., vol. 15, no. 15, pp. 121-132, 2020, doi: https://doi.org/10.3991/ijet.v15i15.14399

[5] L. Medina Herrera, J. Castro Pérez, and S. Juárez Ordóñez, "Developing spatial mathematical skills through 3D tools: augmented reality, virtual environments and 3D printing," Int. J. Interact. Des. Manuf., vol. 13, no. 4, pp. 1385-1399, 2019, doi: https://doi.org/10.1007/ s12008-019-00595-2

[6] D. Tall and B. West, "Graphic Insight into Calculus and Differential Equations," in The Influence of Computers and Informatics on Mathematics and its Teaching, Cambridge University Press, 2011, pp. 107-119. https://doi.org/10.1017/CBO9781139013482.012

[7] M. Artigue and M.-J. Perrin-Glorian, "Didactic engineering, research and development tool: some theoretical problems linked to this duality," Learn. Math., vol. 11, no. 1, pp. 13-18, Oct. 1991, [Online]. Available: http://www.jstor.org/stable/40248001

[8] P. Verillon and P. Rabardel, "Cognition and artifacts: A contribution to the study of though in relation to instrumented activity," Eur. J. Psychol. Educ., vol. 10, no. 1, pp. 77-101, 1995, doi: https://doi.org/10.1007/BF03172796

[9] L. Trouche, "Managing the complexity of human/machine interactions in computerized learning environments: Guiding students' command process through instrumental orchestrations," Int. J. Comput. Math. Learn., vol. 9, no. 3, pp. 281-307, 2004, doi: https://doi. org/10.1007/s10758-004-3468-5

[10] P. Drijvers, M. Doorman, P. Boon, H. Reed, and K. Gravemeijer, "The teacher and the tool: Instrumental orchestrations in the technology-rich mathematics classroom," Educ. Stud. Math., vol. 75, no. 2, pp. 213-234, 2010, doi: https://doi.org/10.1007/s10649-010-9254-5

[11] O. Aldalalah, Z. Waleed Mohamed Ababneh, A. Khaled Bawaneh, and W. Mohammad Mahmoud Alzubi, "Paper-effect of augmented reality and simulation on the achievement of mathematics and visual ... effect of augmented reality and simulation on the achievement of mathematics and visual thinking among students," Int. J. Emerg. Technol. Learn., vol. 14, no. 18, pp. 164-185, 2019, doi: https://doi.org/10.3991/ijet.v14i18.10748 
[12] R. I. Barraza Castillo, V. G. Cruz Sánchez, and O. O. Vergara Villegas, "A pilot study on the Use of mobile augmented reality for interactive experimentation in quadratic equations," Math. Probl. Eng., vol. 2015, 2015, doi: https://doi.org/10.1155/2015/946034

[13] P. Salinas, E. González-Mendívil, E. Quintero, H. Ríos, H. Ramírez, and S. Morales, "The development of a didactic prototype for the learning of mathematics through augmented reality," Procedia Computer Science, vol. 25, pp. 62-70, 2013, doi: https://doi.org/10.1016/j. procs.2013.11.008

[14] M. N. Wangid, H. E. Rudyanto, and Gunartati, "The use of AR-assisted storybook to reduce mathematical anxiety on elementary school students," Int. J. Interact. Mob. Technol., vol. 14, no. 6, pp. 195-204, 2020, doi: https://doi.org/10.3991/ijim.v14i06.12285

[15] K. Liliana et al., "The immersive virtual reality: A study in three-dimensional Euclidean space,” Am. J. Educ. Res., vol. 6, no. 3, pp. 170-174, 2018, doi: https://doi.org/10.12691/ education-6-3-2

[16] S. Cai, E. Liu, Y. Shen, C. Liu, S. Li, and Y. Shen, "Probability learning in mathematics using augmented reality: impact on student's learning gains and attitudes," Interact. Learn. Environ., vol. 28, no. 5, pp. 560-573, 2020, doi: https://doi.org/10.1080/10494820.2019.16 $\underline{96839}$

[17] J. López Belmonte, A. Fuentes Cabrera, J. López Núñez, and S. Pozo Sánchez, "Formative transcendence of flipped learning in mathematics students of secondary education," Mathematics, vol. 7, no. 12, p. 1226, 2019, doi: https://doi.org/10.3390/math7121226

[18] U. Khoerul, N. Toto, P. I. Nengah, H. Erry, and M. Herri, "An application of flipped classroom in mathematics teacher education programme," Int. J. Interact. Mob. Technol., vol. 13, no. 3, pp. 68-80, 2019, doi: https://doi.org/10.3991/ijim.v13i03.10207

[19] N. H. Wasserman, C. Quint, S. A. Norris, and T. Carr, "Exploring flipped classroom instruction in calculus III," Int. J. Sci. Math. Educ., vol. 15, no. 3, pp. 545-568, 2017, doi: https:// doi.org/10.1007/s10763-015-9704-8

[20] M. Artigue, R. Douady, and L. Moreno, Ingeniería didáctica en educación matemática. Un esquema para la investigación y la innovación en la enseñanza y el aprendizaje de las matemáticas, 1st ed. Bogotá D.C, 1995.

[21] R. Douady, "Ingeniería didáctica y evolución de la relación con el saber en las matemáticas de collège-seconde," in Enseñanza de las matemáticas: Relación entre saberes, programas y prácticas, 1996.

[22] J. Godino, C. Batanero, Á. Contreras, A. Castro, E. Lacasta, and M. Wilhelmi, "La ingeniería didáctica como investigación basada en el diseño," Jan. 2013.

[23] T. L. Martin and C. De Assis Olgin, "A didactic engineering for the development of the amortization system theme using the HP 12C calculator emulator," Acta Sci., vol. 21, no. 6, pp. 173-191, 2019, doi: https://doi.org/10.17648/acta.scientiae.5507

[24] D. Calderón and O. L. L. Corredor, "La ingeniería didáctica como metodología de investigación del discurso en el aula," 2012.

[25] L. Espinoza Ramírez, A. Vergara Gómez, and D. Valenzuela Zúñiga, "Contextualización en matemáticas: uso del teorema del ángulo inscrito en la geometrización de la percepción visual," Enseñanza las Ciencias, vol. 38, no. 1, pp. 5-26, 2020.

[26] D. Saraza, C. Vera, J. Trujillo, and R. Prada, "Educational engineering as research methodology in learning the concepts of limit and continuity," Journal of Physics: Conference Series, vol. 1329, no. 1, 2019, doi: https://doi.org/10.1088/1742-6596/1329/1/012021

[27] R. R. de Oliveira and F. R. Vieira Alves, "An investigation of the bivariate complex Fibonacci polynomials supported in didactic engineering: An application of theory of didactics situations (TSD)," Acta Sci., vol. 21, no. 3, pp. 170-195, 2019, doi: https://doi.org/10.17648/ acta.scientiae.v21iss3id3940 
[28] L. Carvalho, R. Martinez-Maldonado, and P. Goodyear, Instrumental genesis in the design studio, International Journal of Computer-Supported Collaborative Learning, vol. 14, no. 1. 2019. https://doi.org/10.1007/s11412-019-09294-2

[29] E. Geraniou and U. T. Jankvist, "Towards a definition of 'mathematical digital competency," Educ. Stud. Math., vol. 102, no. 1, pp. 29-45, 2019, doi: https://doi.org/10.1007/ $\underline{\text { s10649-019-09893-8 }}$

[30] R. Hernández, C. Fernández, and M. Baptista, Metodología de la Investigación, 6th ed. México, 2014.

[31] P. Rabardel, Les hommes et les technologies, approche cognitive des instruments contemporains, Armand Col. Paris, 2004.

[32] "License for educational purpose | Vuforia Developer Portal." [Online]. Available: https:// developer.vuforia.com/forum/license-manager/license-educational-purpose

[33] "Plataforma de desarrollo en tiempo real de Unity | Motor de VR y AR en 3D y 2D." [Online]. Available: https://unity.com/es

[34] G. Brousseau, "La théorie des situations didactiques en mathématiques," Éducation et didactique, 2011, vol. 5, no. 1, pp. 101-104, doi: https://doi.org/10.4000/educationdidactique.1005

[35] R. Duval, "A Cognitive Analysis of Problems of Comprehension in a Learning of Mathematics,” Educ. Stud. Math., vol. 61, no. 1/2, pp. 103-131, Oct. 2006, [Online]. Available: http://www.jstor.org/stable/25472062. https://doi.org/10.1007/s10649-006-0400-z

\section{Authors}

L.H. Carmona-Ramírez received a Bachelor's degree in education with emphasis in mathematics, he also holds a specialization degree in didactics of mathematics and physics and a master's degree in didactics of mathematics from the University of Caldas - Colombia. He is currently an instructor professor of the bachelor's degree in mathematics and physics of the faculty of education and UAFCNyM, and of the master's degree in science didactics at the Catholic University of Manizales, Manizales. E-mail: lucarmona@ucm.edu.co. Her research interests include the field of science, didactics and applied mathematics. He is a member of the Education and Educator Training Research Group - EFE. https://orcid.org/0000-0002-4136-851X.

V. Henao-Céspedes received the B.S degree in electronic engineering, the M.Sc. degree and the $\mathrm{PhD}$. On engineering from Universidad Nacional de Colombia, Manizales. He is currently an Associate Professor at the Academic Unit for Training in Natural Sciences and Mathematics, Universidad Católica de Manizales, Manizales. E-mail: vhenao@ucm.edu.co. His research interests include electromagnetic compatibility, electromagnetic pollution, lightning discharges, internet of things, industry 4.0 , remote sensing. He is a member of the Research Group on Technological and Environmental Development GIDTA. http://orcid.org/0000-0002-1938-3203

Article submitted 2021-07-08. Resubmitted 2021-09-03. Final acceptance 2021-09-03. Final version published as submitted by the authors. 